\title{
Geleneğin Yenilenmesi: Minyatür, Bakış ve Farklı Görme Rejimleri Bağlamında "Fatih Portreleri" Çözümlenmesi
}

Renewal of Tradition; Analysis of Miniature, Sultan Fatih's Portraits in the Context of Sight and Different View Regimes

\section{Aslıhan TONGUÇ*}

Öz

Bu çalışma farklı kültürlerden doğan farklı bakış açılarının oluşturduğu görme rejimlerini karşılaştırmaktadır. Doğrusal perspektif, bakışı merkeze konumlandırarak yeni simgesel biçimler üretirken aynı zamanda bir kültür tekniği de yaratmıştır. Bu çalışmada süreç, bu tekniğin bir diğeri olan minyatür ile karşılaştırılması yoluyla tartışılacaktır. Geleneksel dünyaya ait olan minyatür önem perspektifiyle birlikte tanımlanabilir ve bu bakımdan doğrusal perspektifle birçok yönden karşıtlık içermektedir. Çalışmada; biri Nakkaş Sinan Bey'e, diğeri Gentile Bellini'ye ait olan iki ayrı Fatih Sultan Mehmed portresi seçilmiştir, portreler göstergebilim yöntemi ile çözümlenmektedir. İki kültürün bakış açısıyla konumlandırılan figür olarak padişahın temsillerine yalnızca konumlanışıyla değil, aynı zamanda kullanılan süslemeler ile de yaklaşılacaktır.

Anahtar Kelimeler: Bakış, Görme Rejimleri, Minyatür, Perspektif

\footnotetext{
“ Sakarya Üniversitesi, Sosyal Bilimler Enstitüsü, Kültürel Çalışmalar ABD, aslihan.tonguc1@ogr.sakarya.edu.tr

Bu makale iThenticate sistemi tarafından taranmıştır.

Makale Gönderim Tarihi: 31 Mart 2019
} 


\begin{abstract}
This study compares vision regimes that consist of different perspectives of different cultures. As the linear perspective produces new symbolic shapes by locating the perspective at center, it also formed a culture technique at the same time. In this study, the process will be discussed by making comparison to miniature, another kind of this technique. Miniature belonging to traditional world, can be defined with significance perspective and from this point of view it involves contradictions in many ways. In this study, two portraits of Sultan Fatih Mehmed were considered. One of them is belong to Nakkas Sinan and the other is belong to Gentile Bellini. The portraits were analyzed with semiotique method. Representations of The Sultan as a figure positioned by the perspective of two cultures, will be discussed not only by the way of its positioning, but also by ornament used.
\end{abstract}

Keywords: View, Vision Regimes, Miniature, Perspective 


\section{Giriş}

Sanatın temsil biçimleri vasıtasıyla yapılan göndermeler, geçmişi anlamlandırarak geleneğin sürdürülebilirliğine katkı sağlarken, şimdi de yaşanılan toplumun dinamikleri, gerçeklik algısı ve bakış açılarını göreceli de olsa yansıtmaktadır. Tarihsel bir olgu olarak bakış, sanatçı ve resme dahil olan izleyici açısından her zaman öncelikli olmuştur. Rönesanstan önce ikonoların resme bakana sunduğu ruhani atmosfer yani aura, resme perspektifin dahil olmasıyla kaybolmuş ve perspektif resim merkeze insanı konumlandırmıştır. Daha net ifade edersek perspektifle birlikte bakış resme dahil olmuş ve bakış buyurgan bir kimlik kazanmıştır.

Görmenin anlamı üzerinde doğrusal perspektifin nasıl bir etki ve farklılık oluşturduğunu Belting (2012:21)'in aktarımıyla Heidegger, "Dünya resim oldu” şeklinde ifade etmektedir. Heidegger için bu değişim dünyanın ve insanın temsil edilebilir anlamlarına işaret etmektedir. Doğayı ve çevresinde olup bitenleri gözlemleyerek gördüklerinin temsillerini gözün optik görme kuralları doğrultusunda resme aktaran sanatçı için olduğu kadar bakışı ile bu temsilde özne olarak yer alan insan için de artık dünya seyredilebilir bir resme dönüşmektedir. Fransızca "Renaissance"dan "Yeniden Doğuş" olarak çevrilen Rönesans'1 yeniden doğuran fail, köşeye terkedilmiş Antikite mirasının canlandırılması olmuştur. Yunan ve Roma Medeniyetinin kalıntıları Rönesans'la birlikte insanların gözünde tekrardan canlılık kazanmış ve yeniden anlamlandırılarak eski birikim ile aydınlanma gerçekleştirilmiştir. Rönesans'a karşı yöneltilen bu ilgiyi Krausse (2005:9); “İnsana ilgi, Tanrı, hayat ve her şey hakkında yorum ve bunun için ilk önce kendi aklını kullanmak" olarak özetlemektedir. Aklın öncelendiği ve aklın referans alındığı bu dönem; güzel sanatlar, bilim, kısacası her alanda yönlendirici unsur olarak belirginleşmektedir.

Ortaçağda zengin ve hatırı sayılır kişilerin himayesinde olan sanatçılar daha çok sipariş üzerine, dini içerikli öyküleri resme aktarmışlar ve toplumsal statü açısından birer zanaatkar olarak algılanmışlardır. Rönesans'la birlikte birey anlayışının belirginleşmesi ile onlar da sanatçı kimliklerine kavuşmuş, resme kişisel alg1 ve duyumlarını yani kendilerinden bir şey ekleyebilme ser- 
bestisini kazanmışlardır. Rönesans sanat açısından değerlendirildiğinde sanatçının artık dinsel temalardan daha fazla dünya ile alakalı konulara yönünü çevirdiği bir eşik olmuştur denilebilir. Huberman (2003), ticaretin gelişim serüvenini anlatırken feodal kısıtlamalardan kurtulmak için loncalar kurulduğunu, zaman içerisinde lordlar haklarından vazgeçince toprakların serbest kalışını ve yönetimin böylelikle tüccarlara geçtiğini değerlendirmektedir. Feodalizm yıkılırken bu etkenin yanında barutun ve topun keşfi, ayrıca pusulanın bulunuşunun yeni yerlerin keşfini hızlandırması ve bunun neticesinde ticaretin hız kazanmasını pekiştirmiştir. Bu gelişmeler bir yandan bireyi önceleyeci zemini oluştururken; diğer taraftan da bireyin ilgisini ve merakını çevresine yöneltmiştir. Bu yeni dönemle birlikte dünyayı inceleyen insan için artık gördüğü daha önemli hale gelmiş böyle bir noktada merkezi perspektif yeniden resme dahil olarak, gerçekliğin doğaya uygun taklidini resme aktarmayı hedeflemiştir. Nitekim natüralist sanat biçimlerinin bu dönemde şekillenmesi, Rönesans'ın doğanın görünümünün duygularla algılanılabilen biçimlerini taklit etme mantığı ile izah edilebilir. Rönesans'ın Antikite mirasını canlandırmaya doğru attığı adım, inşa edeceği kimliğini Roma mirası ile tekrardan şekillendirişi bu çalışmanın "geleneğin yenilenmesi ve sürdürülebilir olması" ekseni ile birebir örtüşmektedir. Bu bağlamda birinci bölümde hem bu mirasın nasıl yeni ile eklemlendiği araştırılacak, hem de merkezi perspektifin resme yeniden dahil olma sürecini ve görme biçimlerini Rönesans'ın zihin dünyası içerisinde nasıl değiştirdiği ele alınacaktır. İkinci bölümde minyatür sanatının gelenek içerisinde nasıl kesintiye uğradığı ve kendi içinde tekrara düştüğü sorununun anlaşılmasına ilişkin olarak Osmanlı'da Minyatür Sanatı tarihsel süreç içerisinde incelenecek, minyatür sanatının derinliklerinde yatan görme kültürü önem perspektifi üzerinden tartışılacaktır.

Çalışmamızın son bölümünde ise Gentile Bellini ve Nakkaş Sinan'ın Fatih portreleri karşılaştırılacak ve bu portrelerin egemen görme biçimlerini ne ölçüde yansıttığı ve geleneğin sürekliliğine nasıl bir katkı sağladığı üzerinde durulacaktır. Çalışmanın kuramsal çerçevesinde dil bilimci ve göstergebilimin kuramcıların- 
dan Saussure'un göstergebilimsel analiz metodu kullanılacaktır. Portrelerin düz anlamlarından (gösteren) daha çok verilmek istenen asıl mesajlar (gösterilen) üzerine odaklanılacaktır. Ferdinand Saussere dili kendisiyle birlikte üç parçaya ayırarak yazılı olan kelimeye "simgeleyen" kelimenin işaret ettiği imgeye de "simgelenen" demiş ve her ikisinin simgeyi oluşturduğunu belirtmiştir (Storey, 2010). Göstergebilim, yöntem olarak tıpkı dil gibi bir resmin, bir heykelin veya bir fotoğrafın anlamı nasıl kurduğuyla ilgilenirken resimdeki imgelerin resmi her izleyen açısından farklı açımlamasına olanak sağladığı için çalışmada portreler üzerinden anlamın çok yönlülüğğ takip edilmeye çalışılacaktır.

\section{Rönesans Çağında Bakışın Konumu: Merkezi Perspektif}

Resimde mekan derinliği oluşturmak için kullanılan perspektif tekniği Tansuğ’a göre çok eskilere dayanmaktaydı. Tansuğ (2004:9), Batı'da perspektif kurallarını uygulayan ressamların MÖ 4. yüzyıl yani Helenistik çağa kadar indiğini, Belting ise İbnül Heysem' in teorisini kendince yorumlayarak “Topolojik Optik Mekan Fikri" ni bulan Biagio Pelaconi'nin Floransa'da bunu merkezi perspektif modeli olarak sunduğunu aktarmaktadır (Belting, 2012:155). Perspektifi, Bigalı (1948:648); "iki boyutlu bir alan üzerinde, üç boyutlu bir görünüş oluşturan mekanik sistem" şeklinde izah ederken, Tansuğ (2004:10) ise "Perspektifin geometrik bir sisteme dayandığını ve bununla görsel derinliğin sağlandığını" aktarmaktadır. Merkezi perspektif tekniğinde mantık, gözümüzün çevreyi gördüğü şekli koruyarak yani optik kurallara uygun olarak çizmektir. Doğrusal perspektifle çizim yapılıyorsa nesneleri bulunduğunuz yere göre oradan göründüğü şekilde çizmek esas alınır. Aslında bu durum çizilecek nesnenin karşısında duran kişinin, kişi nesneden uzaklaştıkça o nesnenin bakan kişinin gözünde küçülmesi olarak izah edilebilir. Doğrusal perspektifle çizim yaparken matematik ve geometriyi çok iyi kullanabilen 15. yüzyıl sanatçılarının ilk temsilcisi Giotto olmuştur. Giotto'nun eserlerine imza atan ilk sanatçı olması bakımından bireyciliğe yaptığı katkı önemlidir. Giotto'yu takiben Masaccio ise perspektifin anlamını resimlerinde hissettiren ve o günkü Floransalılar için görme alışkanlıklarını ters yüz eden çalışmalarıyla öne çıkmaktadır. Giotta 
zamanında gizlice usta-çırak öğrenimi tarzında ilerleyen perspektif eğitimi, 1435 'te Alberti'nin "Resim Sanatı Üzerine" adlı eserinde alenen mevzu olmuştur. Krausse (2005:9) Alberti'den, perspektif ilkelerini matematiksel formüllerle açıklayan kişi olarak bahsetmektedir.

Rönesans sanatı Gotik sanatın dini temaları resme aktarışındaki insanüstülüğü terkederek Beksaç (2000 :21)'ın bakış açısıyla “dinle bütünleşen bir doğa ve idealize olmuş bir insan anlayışı" getirmektedir. Beksaç (2000:22) Rönesans sanatçlarını, "önceki devirlere kıyasla kendinden son derece emin ve yaptığının bilincinde olan kişiler" şeklinde nitelemektedir. Değerlendirmeler gösteriyor ki Rönesans sanatçlarının kendilerine güvenlerinin temelinde, Eski Roma ve Yunan sanat eserlerini yani geçmişin derinliklerini dayanak almaları yatmaktadır. Bu durum Hobsbawm (2006: 2)'nun geleneğin icadını tartışırken örnek verdiği Britanya Parlamentosunun 19. yüzyılda yeniden inşa edilirken tercihini bilinçli bir şekilde Gotik tarzdan yana kullanmasına benzetilebilir. İlkinde Rönesans kendini Antikite ile yenilemiş ikinci örnekte ise Parlemanto binası Gotik sanatı referans alarak kendini tanımlamıştır. Netice olarak dayanak alınan tarihsel referanslar yeni kimliklerine gelenek içerisinde süreklilik kazandırmaktadır.

Panofsky (2012: 1) perspektif kavramını Dürer'in izahıla Latince "Perspectiva" ile "içinden bakmak" şeklinde aktarmakta, Krausse (2005:9) ise Alberti'nin resmin yüzeyini, ressamın dünyaya baktığ1 "açık bir pencere" ye benzettiğini ifade etmektedir. Pencere kavramı ile ilişkili diğer bir kavram olan "Kaçış noktası" ise geriye doğru giden tüm çizgilerin tek noktada birleşiyor gibi çizim yapılması olarak izah edilmektedir. Krausse (2005:9) resimdeki her şeyin tek bir noktaya, kaçış noktasına doğru aktığı merkezi perspektifte resmin derinliklerine doğru bulunan bu kaçış çizgilerinin hayali bir kaçış noktasında birleştiğini belirtmektedir. Hayali kaçış çizgilerinden meydana gelen üçgenin içerisinde Krausse (2005:122) nesneler ve insanların uzaklık ya da yakınlıklarına göre değerlendirildiğini aktarmıştır. Resme bakanları tek bir bakışta toplayıp, resmin içine çeken bu teknikte ressam gerçeklik duygusunu karşı tarafa aktarımda oldukça başarılı ve etkili olmuştur. 
Nitekim Rönesans ressamlarının çoğunluğu resimlerini tek kaçışlı perspektifle çizmeyi tercih etmişler, bir taraftan da düzen, denge ve simetri sağlayan bu teknik gerçekliği birebir tasvir etme isteklerini gerçekleştirmede ressamlara kolaylık sağlamıştır. Sanatçıların merkezi perspektif kurallarına doğru yaptıkları bu eğilimi değerlendiren Krausse (2005:9) sanatçlların bu teknikle artık kendilerini "dünyanın düzenleyicisi" konumuna taşıdıkları yönünde görüş bildirmektedir.

Resimde mekan derinliği oluşturmak isteyen perspektif, yukarıda belirtilen açık pencere kavramını yani yeni bir mekanı resimde oluşturmaktadır. Oysa ki Tansuğ (2004: 10)'un da aktardığ1 gibi yüzeyci Bizans ve Ortaçağ resimlerinin gerçek mekanı, yer aldıkları tarihsel yerin mekanı olduğu için seyirci resimle ruhani birlikteliği daha çok hissedebilir, çünkü orada aura muhafaza edilmektedir. İkonolarda, minyatürde veya perspektif kurallarının bilinçli bir şekilde ihmal edildiği bazı resimlerde içtenlik ve ruhi yakınlığın daha derinden duyumsanması da auranın korunması, ayrıca sanatçının bireysel duyuş ve anlayışını da resme dahil edebilmesinden kaynaklanmaktadır. Bir tarafta gerçeği perspektifin katı ve geometrik ölçümlerinin içinde idealize eden sanatçı, diğer yanda gerçeğe düşündükleri ve önemsediklerini katan sanatçı bulunmaktadır. Tarihsel süreç içerisinde resmin anlamı fotoğraf makinası ardından sinema makinesinin icadı ile değişirken artık izleyici bir klasiğin önünde durarak kendini resmin içine dahil etmeden resim seyirciye gelmekte ve resmin anlamı çoğalmaktadır (Berger 2016:20). Resmin anlamının değişmesini ve buna bağlı olarak görme biçimlerinin farklılaşmasını Benjamin, sanat yapıtının tekniğin olanakları sayesinde yeniden üretilebilmesiye açıklarken tıpkı "Katedralin bir sanatseverin stüdyosuna gelmek için bulunduğu yerden ayrılması" benzetmesinde değindiği gibi, sanat yapıtının "şimdi ve buradalığının" yani "biricikliğinin ve hakikiliğinin" kaybolduğunu belirtmektedir (Benjamin 2009:54). Perspektif ile sanat eseri karşısında birey olarak konumlanan sanatçı devamında mekanik çoğaltma ile aurasını yitiren sanat eseri beraberinde bireye yeni bir görme biçimi getirmiş, bu değişim büyük ölçekte tarihi süreç içerisinde görme kültürlerini dolayısıyla 
bakışı tektipleştirmiştir. Oğuzhan (2008), perspektifin "aracıl1ğıla görme" anlamı ve perspektifin tüm niteliklerini içerisinde barındıran "kitlesel görüntü" izlekleri üzerinden deneyimin de aynılaştığını aktarmaktadır. Merkezi perspektife dayalı görme biçimi ile alternatif görme biçimlerinin karşılaştırılmasındaki temel amaç görme biçimlerinin tarihsel süreç içerisinde nasıl aynılaştığını ortaya çıkarabilmektir. Oğuzhan (2008)'ın görme biçimlerinin bu merkeziliğinin kırılarak yerine ikonografi, tasvir gibi çok görüşlü biçimlerin getirilmesi ile düşünmenin en temel kaynağı olan görmenin daha çok yönlülüğe ve eleştirel okumalara kapı açacağ1 ve kendi deyimiyle "dünyaya ilişkin bilgiyi sorgulama kanalları açabileceği" değerlendirmesi oldukça önem teşkil etmektedir. Nitekim bireyin görme rejimleri anlamında seçim yapabilerek çok yönlü, çok bakışlı bir konum alması kritik ve analitik düşünme becerileri oluşturabilme yönünde belirli kodlardan bağımsız hareket edebilmesinin önünü açacaktır. Perspektif ile tek merkezli egemen bakışa dahil olan bireyi tasvir ederken resmin Panofsky (2012) perspektifin, izleyiciyi önünde ve dolayısıyla dünyada ayrıcalıklı bir yere konumladığını değerlendirmiş, bu sabitlemenin bireyi yücelttiği sonucunu çıkarmıştır. Berger (2016: 18) ise bu tarz bir bakma biçiminin seyirciye dünyanın biricik merkezinin kendisi olduğuna inandırdığını düşünmektedir. Aynı zamanda Belting (2012)'in Rönesans'in kutsallık atfettiği bireyi bir hamlede iki kez resme koyduğuna yaptığı atıf, 2000'li yıllardan itibaren Batı ve Doğu dünyasında özelde Türkiye' de bakışın geçirdiği evrilme, bu tespitlerle birebir örtüşmektedir.

Perspektif resim önünde bakışıla dünyaya tahakküm eden ve portre ile kendisini seyreden kişi bugün hangi görme biçimiyle bakmaktadır? Küresel anlamda popülerite kazanan perspektif ideolojisi 2000 yılından bu yana oluşan teknolojik gelişmeler ışığı altında değerlendirildiğinde Doğu veya Batı tarzı görme biçimlerini birbirine dönüştürmüştür. Perspektifin bugün tüm dünyada görme teknolojileri ile yaygınlaşmasına televizyon, basın ve yeni medya araçları aracılık etmektedir. Yeni bir görme biçimi kazanan birey artık bakışıyla dünyayı kendine ait olarak görmektedir. Belting (2012)'in perspektifin Yeniçağ kültürünü ifade eden “sim- 
gesel bir biçim" olduğunu ileri sürmesi bu bakışı sadece sanatın meselesi olmaktan çıkararak bir kültür tekniği olarak tanımlamasinda etkin olmaktadır. Florenski "Dünyanın perspektifle yapılan temsili, teatraldir" ifadelerinde yaşamın gösteri olarak belirginleşmesine vurgu yaparken, aslında hakikat duygusunun kaybolduğu, sorumluluk bilincinin yitirildiği bir dünya görüşünün derinliklerini de perspektifle ilişkilendirmektedir (Florenski,2013: 61). Bu tartışmaların bir başka boyutu olarak "Simgesel bir biçim" metninde Panofsky meseleyi iki ucundan yakalayarak yüzleştirmektedir:

"Perspektif tarihi, mesafe koyan ve nesneleştiren türden bir gerçeklik duygusunun zaferi olarak anlaşılabileceği gibi, insanoğlunun mesafeyi reddeden iktidar çabasının zaferi olarak da aym şekilde dış dünyanın sabitleştirilmesi ve sistematikleştirilmesi, insan benliğinin kendi alanmı genişletmesi olarak da anlaşılabilmektedir" Panofsky (2012: 53).

Perspektifin kültür tekniği olarak ve simgesel bir form olarak siyaset, ekonomi, sanat gibi birçok konudaki yönelimleri ile etkileşimi, yeni bir düşünsel düzlemde varlığı, kuramcıların bu konuya sıklıkla yaptığı atıflardan da anlaşılmaktadır.

\section{Geleneğin Sürekliliği Bağlamında Minyatür Sanatı}

Minyatürün kadim bir geçmişi olduğunu arkeolojik çalışmalar kanıtlamaktadır. Uygurlar dönemi Türklerde minyatür geleneğinin başladığı ilk dönem olurken, Selçuklu Türklerinin Anadolu'ya yerleşmesinden sonra ise minyatür sanatı gelişimini o bölgede devam ettirmiştir. Türk resim sanatının klasiklerinden sayılan minyatürün Osmanlı sanatında oldukça ilgi görmesini İnel (1999: 40), bu sanatın yaşamla içiçe olmasıyla ilişkilendirmektedir.

Minyatür teriminin kırmızı boya "minium"dan türetildiğini ve yazma eserlerdeki kitap resimlerine minyatür denildiğini Mahir (2012) aktarmaktadır. Minyatürün kelime kökünün Latince "minium" maden kırmızısı anlamını taşıdığını ifade eden İnel (1999), bu kelimenin Fransızca' da ise "küçük, çok küçültülmüş" anlamını taşıdığını belirtmektedir. Minyatür resimde yapılan temanın barındırdığı olayları görselleştirmek için olayı resme figürler halinde ve figürler birbirini kapamayacak şekilde yerleştirme işlemidir. 
İran'dan Makedonya'ya kadar farklı minyatür türleri bilinmekle birlikte bu çalışmada Osmanlı Minyatür Sanatı konu edilecektir.

Batı' da bu sanatın kökleri antik çağlara inerken Türkler'de minyatür geleneğinin Orta Asya'da Uygurlar döneminde ortaya çıtığ ve bunun da İslam öncesi dönemlere rastladığı bilinmektedir. Uygur minyatürlerinin İslam minyatürünün kaynağı olduğunu aktaran Aslanapa (1972: 14-15), Eski Uygur şehirlerinin harabelerinde 8. ve 9. yüzyıllardan kalma Budist ve Maniheist duvar resimleri ile minyatürlerin varlığından bahsetmektedir. Renda (1992), Osmanlıların minyatüre yeni bir resimsel anlatım ve yeni bir konu dünyası getirdiklerini aktarmış, İnel (1999), ise Osmanlı minyatür sanatının zaman içerisinde kendisine özgü bir ekol oluşturduğunu belirtmiştir. Selçukluların İran ile ilişkilerine bağlı olarak minyatür sanatı uzun zaman İran etkisinde kalmış, Osmanlı minyatür sanatı Selçuklu ve İran minyatürlerinden etkilenmiştir. Bu etkilenmeyi avantaja dönüştüren Osmanlı minyatürleri bu eski kültürlerin etkileri nedeniyle güçlü karakteristiklere sahip olmuşlardır. Yalnız Titley (1983) 'in ifadesiyle, Osmanlı minyatürleri her ne kadar başlarda bu etkiyi İranlı sanatçıların ve minyatürlerin etkisinde olmalarına borçlu olsalar da Türk sanatçllar kendilerine özgü bir resim anlayışı geliştirmişler ve kendi uslüplerini oluşturmuşlardır.

Doğu tasvir geleneğinin izlerini taşıyan ilk dönem eserleri İstanbul'un Fethi ile yepyeni bir döneme geçmiştir. Fatih'in Batı tasvir geleneğine karşı takındığı olumlu tavır ve bu tutumunu harekete geçirici girişimleri minyatür geleneği için yeni bir boyut ve yeni bir dönem başlamasına zemin oluşturmuştur. Osmanlı minyatür koleksiyonlarının Türk gösteri sanatının bütün çeşitliliğini kapsadığını değerlendiren Titley (1983), bu bütünün içeriğini romantik şiirler, ansiklopedik çalışmalar, ontolojiler, portre albümleri ve resimler, epikler, kronikler, tarihler, fabllar, haritalar ve kâğıt kesme çalışmaları olarak aktarmaktadır.

Minyatür yazmalarının konuları arasında bayramlaşmalar, meclis sahneleri, padişahın huzurunda düzenlenen eğlenceler, devlet adamlarının huzura kabulü yer alırken yine tahta çıkış konulu tasvirler içerisinde Topkapı Sarayı'nda yapılan cülus törenlerini 
gösteren minyatürler de mevcuttur. Divan toplantısı, hilat verilişi gibi konu içerikli minyatürlerin mevcut olması sonraki nesillerin de Osmanlı Sarayı'nın protokol kurallarını, merasim tavırlarını öğrenmesini sağlamaktadır.

Kanuni Sultan Süleyman dönemi ile birlikte Çağman'ın değerlendirmesiyle "Türk resminin benliğini kazandığı dönem"e geçilmiştir. Tarihsel konulu yazmaların önem kazandığı bu dönemde Şahnâme veya Şehinşahnâme adlı eserler bu türe önemli örneklerdir. Matrakçı Nasuh tarafından yazılan ve resimlenen "Süleymanname" eseri minyatür sanatının gelişimini göstermesi açısından önemlidir. Mahir (2012), Matrakçı Nasuh'un “Topografik Ressamlık" denilen yeni bir tasvir türünü minyatüre kazandırdığını aktarmış, Bağ cı vd. (2006) ise Nasuh ve onun ekolünü takip eden sanatçıların manzara ressamlığında bıraktıkları belgelerle, şehircilik araştırmacılarına sağladıkları katkıyı değerlendirmişlerdir. Fotoğrafın olmadığı bir zaman diliminde 16. yüzyılda kentlerin durumlarını bu kadar ince detayıyla resme dökebilmesi, figürsüz manzara ressamlığında Matrakçı Nasuh'u avangart yapmaktadır. Nitekim Nasuh'un bilinen bir özelliği çizdiği minyatürlerde insan figürü kullanmayışı olmuştur (Çağman ve Tanındı, 1974: 57).

Mahir (2012)'in Klasik Osmanlı Minyatür Üslubunun kurucusu saydığı Nakkaş Osman ise kendine özgü kompozisyonları ile Osmanlı minyatürüne yön vermiş bir sanatçıdır. 3. Murad'ın Şehzadesi Mehmed için yapılan sünnet düğünü Nakkaş Osman'ın denetimindeki nakkaşlar tarafından Surname-i Hümayun içerisinde 437 minyatürle resimlendirilmiştir (And 2014: 81). Elli iki gün süren sünnet düğünü şenliklerini konu alan bu minyatür resimleri, düğünün ihtişamını yansıtmakla kalmayıp her sınıftan insanın temsilini aktararak İstanbul halkının yaşamını da takip edebilme imkanı sunmaları açısından önem taşımaktadır (Bağcı vd., 2006: 145). Nakkaş Osman'ın bu sünnet düğününü sinema gibi belgelediğini değerlendiren Tanındı (1996: 42) bu eserin Osmanlı ekonomisi, eğlence kültürü ve tiyatrosu hakkında bize sunulmuş belgeciliğine de atıf yapmaktadır.

18. yüzyıl Lale Devri'nde ise Levni mahlasını kullanan Abdülcelil Çelebi önemli bir sanatçı olarak öne çıkmaktadır. Klasik minyatür 
geleneğinin dışına çıkan Levni Batı resim geleneğini eserlerinde etkin olarak kullanmıştır. Levni'nin eserlerindeki derinlik kazandırılmış kurguların Mahir (2012), minyatüre yeni bir soluk kazandırdığını değerlendirmiş And (2014) ise Levni' nin minyatürlerinde bedenin duruşu, kumaşın kıvrımları, saydam tüllerin betimlenişindeki ustalığa dikkat çekmiştir. Levni'nin Avrupa portrelerindeki gibi dekor inceliklerine inmesi, portrelerde yüzleri daha canlı ve doğal bir şekilde çizmesi yeniliğe dönük taraflarını kanıtlarken çizdiği resimlerde kullandığı tezhipler, motifler ve geleneksel imgeler de gelenekçiliğine vurgu yapmaktadır. Levni gelenekle yeniliği birleştirmeye çalışarak minyatür sanatına gelişim sağlasa da dönemini tek başına simgeleyen bir kişilik olmuştur (Bağcı vd., 2006: 268). Gelenekle yeniliği buluşturma çabasında tek başına yeterli olamayan Levni'den sonra da minyatür sanatına bireysel çabalar düzeyinde katkılar verilmiş fakat minyatür sanatının tarihi geçmişi içerisinde yenilenerek süreklilik gösterebilmesi sağlanamamıştır. İpşiroğlu (2012: 51), bu döneme kadar canlılığını sürdüren geleneğin aynı konuların tekrar edilmesi ile kendi içinde tazelenemediğini netice olarak bu sanatın donduğunu ve tekrara düştüğünü değerlendirmektedir.

\section{Varoluşun Uyumuna Sadık Kalmak: Önem Perspektifi}

Farklı uslüplerin sentezi olarak ortaya çıkan İslam minyatür sanatındaki temel tavır, insanın Yaratıcı karşısında yaratılmış olarak aciz kaldığının kültürel ve toplumsal bir olgu olarak benimsenmesi, bu izleğin resimlendirilme biçimindeki stilizasyon ve semboller üzerinden okunabilir olmasıdır. İslam düşünce dünyasının temelinde yaratmak sadece Allah'a mahsus edilir. Bu düşünce dünyasında, yaratılmış olan insan gördüklerini temaşa etmektedir, dolayısıyla kendini özne olarak değil, kul olarak konumlandırmaktadır. Nakkaş görüneni salt gerçeklik olarak resme aktarmayarak, aslında düşündüğü ile sentezleyerek görünenden görünmeyene bir yol bulma çabası içerisinde sanatını icra etmek niyetini taşımaktadır. And "Osmanlı minyatürünün üç boyutluluk duygusunu veren optik yanılsama etmenlerine yabancı olduğunu" belirtirken eserlerde çizimsel perspektiften uzak durulduğunun da altını çizmektedir (And, 2014: 174). 
Minyatürde nesneler çizgi perspektifindeki gibi gözümüze uzaklığa göre değil, resmin içerisindeki önemine göre yerleştirilmektedir. Sınırlı bir alana birçok olayın resmedilmeye çalışılması bu tercihte önemli bir etken olmaktadır. Olayın örgüsünde önemli olan figürler iri resmedilerek daha belirginleştirilirken daha az önemi olan figürler üst tarafta tasvir edilmektedir. Bu sebeple de minyatür sanatı, önem perspektifi olarak sınıflandırılmaktadır. İkonolarda da tersten perspektif kullanılmıştır. İkonoların paralel perspektife uygun düşmeyişinin rastlantısal olmadığını düşünen Florenski, perspektif yasalarına aykırı davranılmasının estetik açıdan taşıdığı verimliliğe vurgu yaparak perspektif kurallarına sıkı sıkıya uyarak yapılan çizimlerin daha sıkıcı ve ruhsuz bir etki bırakırken perspektif hataları bulunan daha uyumsuz çizimlerin ise öfke yerine insanların hoşuna gittiğini ifade etmektedir Florenski (2013: 40-41). Minyatür eserler izleyiciye albümler içerisinde resimlenirken sanki izleyen oradaki anlatıyı kitap okur gibi gözü, resimleri birbiri ardına takip edebilecek tarzda tasarlanmıştır. $\mathrm{O}$ an anlatı nerede geçiyorsa kişi orada konumlanarak samimiyet ve içtenliği hissedebilecek şekilde bir stilizasyonla resmedilmişlerdir. Burada nakkaşın asıl hedefi sanatın değişmez kurallarına uygunluk değil içtenliği yakalama çabası olmaktadır.

İkonolarda, minyatürlerde ve Anadolu temsil biçimlerinden olan yazı resimlerde merkezi perspektifte olduğu gibi göz hakim bir konumda değildir. Florenski'nin çok merkezliliğin egemen olduğunu tespit ettiği bu resimlerde, optik görme kurallarına göre perspektifle görülmesi imkansız olan kısımları da gösterme olanağ1 sağladığı için bu teknik çok merkezli kabul edilmiştir. Gözü tek noktaya sabitlemeyen göze değişik bakış açılarından bakabilme olanağı sunan bu sistemin, Florenski (2013: 26-27) bilinçli olarak gözü şaşırtacağını ve gözün imge üzerinde kuracağı cumhuriyete engel olacağını savunmaktadır.

Önem perspektifini kullanan sanatçının niyeti gerçekliğe kendi düşünsel ve ideal ettiği dünya görüşünden müdahaleler yapma hamlesi ile de ilişkilidir. İkonalarda İncil'i kalın veya farklı bir renkte çizilmesi, minyatürlerde Sultan'ın hangi konu dünyasında olursa olsun en belirgin ve önemli çizilmesi buna birer örnek teş- 
kil etmektedir. Nitekim perspektif çizimle tekniğe uygun olarak resmedildiğinde görülmesi mümkün olmayacak olan bir yüzeyin bu şekilde belirginleşerek, öne çıkarılması için tersten perspektif verimli bir yol olmaktadır. Sabitlenmiş bir odak noktasının yerine farklı imgelerin renk veya ışık dağılımı kullanılması önem verilen imgenin belirginleştirilmesi için artı yönde katkı sağlamaktadır. Merkezi perspektifin Mısır'dan beri bilindiğini ama bilinçli bir tercihle kullanılmadığını aynı şekilde İslami temsil biçimlerinde aynı tercihin yapıldığını savunan Florenski bu iradi seçimin derinliklerindeki düşünsel arka planı şöyle özetlemektedir:

"Amaç görünmeyenle görüneni benzeştirerek onlar üzerinde hükümranlık kurmak değil, bir çocuk saflğ̆ryla görünmeyene hayran olmak ve teslimiyet duymak, onun benzeşim ilkesi sayesinde ele geçirilemeyeceğini teslim etmektir" (Florenski, 2013: 13).

Tersten perspektifin ifade edilen bu düşünsel arka plan tıpkı minyatürün görme kültürünün derinlikleri ile aynı kökten beslenmektedir; bu da yaşamın üzerinde tahakküm kurma yerine yaşama sadakat duymayı ve sanatın tüm temsillerinin Yaratıcının sonsuz varlığının simgeleri olarak okuma anlayışına dayanmaktadır.

\section{Batı Ve Doğu'nun Bakışması: “Minyatür Portreciliği”"}

Hristiyan dünyası için kutsal bir öneme sahip olan İstanbul'u fetheden Fatih Sultan Mehmet bu fetihle birlikte hem Batı hem Doğu'nun bakışlarını üzerine çevirmiş, fetihten sonra İstanbul'un Doğu ve Batı'yı birleştiren bir köprü olması için İstanbul'u kültürel açıdan imar etmeye çabalamıştır. Fatih'in Sarayı'nın kapısındaki kitabeye Çağman (1976: 893)'ın aktarımıla “İki kıtanın hükümranı, iki denizin hakimi, her iki dünyada Allah'ın gölgesi, Doğu ve Batı arasında Allah'ın yardımcısı" olarak yazdırması Sultanın kendisini konumlayışı hakkında fikir vermektedir. Yüzünü her iki yöne çevirebilen, vizyonu geniş bir Sultan olan 2. Mehmet, İmparatorluğu inşa ederken yabancı tarih, kültür ve sanat birikimlerini de değerlendirmiştir. Refik (2012: 12)'in Batılı elçilerden aktardığına göre 2. Mehmet, Büyük İskender, Julias Sezar'ı incelemiş, Yunan şehir devletlerinin siyasi tarihini ve Roma imparatorlarının, Fransa krallarının tarihini araştırmıştır. Fatih'in geleneğin 
yenilenmesi anlamında oldukça Batılı bir zihin dünyasının tezahürü olan portre konusunda attığı adımlar, bu olguyu nasıl okuyabileceğimize dair argümanlardır.

Rönesansin insana olan ilgisi, insan bireyselliğinin öncelikli göstergesi olan yüzün incelenmesini böylelikle de portre ressamlığını ortaya çıarmıştır. Ressamlar önceleri yüzü yandan resmetmişler, daha biricik ve eşsiz bir ifade vermek için seçtikleri bu tarzı 15. yüzyılın ikinci yarısında terketmişler, dörtte üç profili tercih etmişlerdir (Krausse, 2005: 11). Böylelikle yüz tasviri için bireyin ayırt edici özelliklerini, karakterini daha iyi tasvir edici bir çizim imkanı sağlamışlardır. Osmanlı Sultanlarının portrelerinin yapımına ise Fatih Sultan Mehmed döneminde başlanmış yaklaşık beş yüzyıl boyunca devam edegelmiştir (Raby, 2000: 18). Osmanlı Minyatür Sanatında padişah portreciliği geleneğinin birinci ayağını Avrupalı sanatçıların İstanbul'a davet edilerek çizdiği portreler oluştururken, ikinci ayağını da Saray nakkaşlarının Batılı sanatçılardan aldığı resim eğitimi etkisi ile çizdikleri portreler belirlemektedir. Bu bağlamda 2. Mehmet'in Avrupalı sanatçıları portre ve madalyalarını yaptırmak için İstanbul'a davet etmesi, Saray Nakkaşı Sinan Bey'i resim eğitimi almak üzere Venedik'e göndermesi örnek olarak verilebilir (Raby, 2000: 70).

Mahir (2012), Osmanlı tasvir sanatında padişah portreciliğinin 1480 'li yıllarda Fatih'in gül koklayan portresi ile başladığını ifade ederken Necipoğlu (2000), Osmanlı portreciliğinin Timurlu ikonografi geleneğinin etkisinde olduğunu ve gül koklayan Fatih Sultan portresinin bu izleri taşıdığını aktarmaktadır. Nakkaş Sinan Bey ve öğrencisi Şiblizâde Ahmed'in Osmanlı'da padişah portreciliği ekolünü başlatan kişiler oldukları düşünülmektedir. 13. yüzyılda yaşamış minyatür sanatçılarından olan Nakkaş Sinan, Fatih Sultan Mehmet tarafından İtalya'ya gönderilmiş, İtalyan ve Rönesans resim sanatını kendi geleneği içinde sentezleyerek kendine has minyatür portreciliği tarzını oluşturmuştur. Sinan Bey'in Mastori Pavli'nin öğrencisi olduğunu ve yetiştirdiği Bursalı Ahmet Şiblizade' nin de portre yapan sanatkârların en iyisi olduğu 16. yüzyıl yazarlarından Mustafa Ali tarafından aktarılmaktadır (İnalcık ve Renda, 2009: 894). 
Nakkaş Sinan'ın yetiştirdiği talebeler geleneğin devamlılığını sağlamada minyatür sanatına olumlu katkılar sağlamışlardır. Sinan'ın yetiştirdiği Şiblizade Bursalı Ahmet, Gelibolulu Mustafa Ali, Hüseyin Bali, Taceddin Kürebend, İbrahim Çelebi, Galatalı Memi, Kıncı Mahmut, Hasan Dede, Mehmet Siyah Kalem bu geleneğin öncü sanatçılarıdır (İnel, 1999: 41). Osmanlı Nakkaşhanesinde yerli sanatçılar bir yandan geleneksel İslam resim sanatı üzerine çalışmalar yapmışlar bir yandan Fatih' in teşvikiyle Batı'nın resim tarzını öğrenmişlerdir. Sarayda çalışan yabancı ressamlar ise Osmanlı resim sanatı üzerinde tesirler göstermişlerdir.

Venedikli ressam aile Bellini'lerden ünlü ressam "Gentile Bellini" nin 1479-1480' de İstanbul'a gelmesi ve padişahın portresini yapması da bu başlık altında önemli bir süreçtir. Gentile Bellini, 1428' de doğmuş, Venedikli bir ressamdır. Refik (2012: 15) aktar1mına göre, babasından miras kalan "Devlet Ressamlığı" payesi sayesinde Dukaların portrelerini yapmıştır. Bellini, ilk önceleri sarayda eskiz denemeleri yapmıştır. Sanatçının çizdiği Fatih portrelerinin sayısı hakkında ise tarihçiler arasında net bir fikir birliği sağlanamamıştır.

2. Mehmet'in ölümünden sonra portrede bir duraksama yaşansa da sonraki yıllarda Nakkaş Nigari, Osmanlı padişah portreciliğinde yeni bir atılım yapan isim olmuştur. Matrakçı Nasuh Doğu ile Batı geleneğini harmanlayabilen önemli bir nakkaş olarak geleneğe katkı sağlamıştır. Osmanlı' da padişah portreciliği 18. yüzyılda yeni biçim ve tekniklere kavuşmuş, guaj veya yağlıboya portreler yapılmaya başlanmıştır. Renda bu durumun portrelerin artık duvara asılmak üzere yapıldığını ve portrelerin taşınabilir resim niteliğine kavuştuğunun işareti olarak yorumlamıştır (İnalcık ve Renda, 2009: 939). Böylelikle portreler nitelik değiştirerek taşınabilir resim niteliği kazanmışlardır, fakat bir yandan da fotoğrafın icadına kadar bir çok padişah portresi albümü hazırlanarak, bu gelenek devam ettirilmiştir (Bağcı vd., 2006).

Fatih Sultan Mehmed'in, Batı görme kültürüne ait olan portre ve dolayısıyla bireyselliği öne çıkarıcı, yüze odaklanan portre konusunda takındığı tutum, yerli ve yabancı sanatçıların çalıştırıldığ1 Nakkaşhanenin sanatsal işlevleri ve portrenin minyatür sanatı ile 
bütünleştirilme çabaları Fatih dönemini geleneğin yenilenmesi bağlamında özellikli kılmaktadır.

\section{Analiz}

\section{Fatih Portreleri Mukayesesi}

Bu çalışmada analiz için seçilen iki portreden ilki Topkapı Sarayı Müzesi Yakup Bey albümünde yer alan Fatih'in gül koklayan portresi, diğeri Londra National Gallery'de bulunan Fatih'in yağlı boya portresidir. Resimlerin seçilme sebebi portreleri yapan Nakkaş Sinan Bey ve Gentile Bellini'nin farklı kültürlerden gelen ve farklı görme biçimleri ile bakan sanatçılar oluşu, iki perspektifi kıyas imkanı sunabilmesi çalışmanın bakış eksenini tartışmaya olanak tanımaktadır. Ayrıca Nakkaş Sinan Bey portresi, üzerindeki göstergelerin geleneğin devamlılığını nasıl açıkladığının okunmasına ait önemli iletiler barındırmaktadır. Göstergebilimin dil dişı alan ve salt dilsel olmayan iletişimi kapsayan yönü ve Saussure'a göre göstergenin temelde temsil etme işlevi çalışmaya uyarlanmıştır. Bu bağlamda görüntüsel gösterge olarak Fatih'in portresindeki yüz ifadesi, giyim tarzı, mimikler, takılar ve portreye ait diğer sembol ve işaretler düz ve yan anlamlar açısından çıkarımlar yapılarak, göstergelerin alımlayıcısı olarak okunacaktır.

Topkapı Sarayı Müzesi Yakup Bey albümünde yer alan (Çağman ve Tanındı, 1979: 54) eser, Fatih'in gül koklayan portresi olarak tanınmıştır. Raby (2000: 82)'e göre Fatih'in elinde çiçek tutan imgesi 1579' da Nakkaş Osman tarafından Şema'ilname'ye uyarlanmış ve Paolo Giovio'nun Osmanlı portrelerinin aynı dönemde yayınlanmasıyla da Avrupa geleneğine geçmiştir. Fatih'i azametli bir şekilde tasvir etme imkanı veren Rönesans portrelerindeki gibi hafif yana dönük poz ve bağdaş kurarak rahat oturuş pozu ile çizilmesi Timurlu portrelerinden esintiler olduğu yönünde değerlendirilmiştir. Renda (1992), bir yandan Batı resminin gölgeleme tekniklerini bir yandan İslam minyatürüne özgü çizim stilinin portrede sentezlendiğini belirtmektedir. 


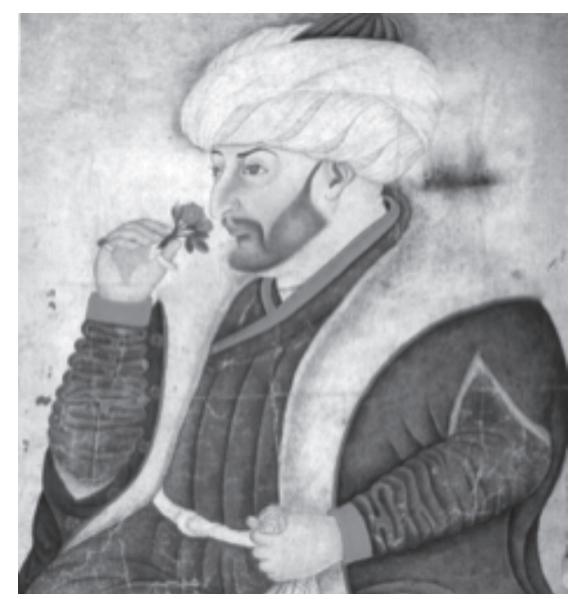

Resim 1. Gül Koklayan Fatih Sultan Mehmed Portresi, Şiblizâde Ahmed'e atfedilir. 1480 civ, TSM, H.2153, y. 10a (Padişahın Portresi Tesâvir-i Âl-i Osman, Türkiye İş Bankası Yayınları, İstanbul 2000, s. 82).

Göstergebilim yöntemini geliştiren Barthes (1976)'1n, göstergenin neyi temsil ettiğini belirten düz anlam ve göstergenin nasıl temsil edildiğine ilişkin olan yan anlam metoduna göre Sultan'ın tevazu sahibi olduğu ve sade bir yaşam stilini tercih ettiğinin anlami, portrede yere bağdaş kurarak oturma tarzı ile verilmektedir. Tablodaki ulema sarığı göstergesi İslami kimliğine ve toplumsal statüsüne işaret etmektedir. Fatih'in Hz. Muhammed'e olan sevgisinin anlamı gülü elinde tutması ve gülü koklaması ile verilmiştir. Bu anlama paralel olarak elinde tuttuğu mendil göstergesi yan anlamlar olarak Fatih'in aşk ehlinden ince ruhlu bir kişi olduğuna ve bu muhabbetin iletişimine gönderge yapmaktadır. Çünkü Türk kültüründe mendil remz'i sevenlerin haberleşme aracı olmasıdır.

Göstergebilimsel çözümlemelerde kuramın temelini oluşturan gösterge, gösterilen (asıl mesaj) ve gösteren (düz anlam) bu portreye uyarlandığında başparmağa takılan "zihgir" göstereni Fatih'in askeri yönüne gönderme yapmaktadır. Kaftan rengi olarak seçilen mavi renk gösterdiği düz anlamın ötesinde ferah ve rahatlık anlamı asıl verilmek istenen mesaj olmaktadır. Fatih'in yeniliklere açık, batıya dönük ve entellektüel dünyasının anlamını portrede 
Nakkaş Sinan'ın giysilerin kollarında kullandığı kıvrımlar ve gölgeleme teknikleri ile alımlayıcıya hissettirilmektedir (Resim 1).

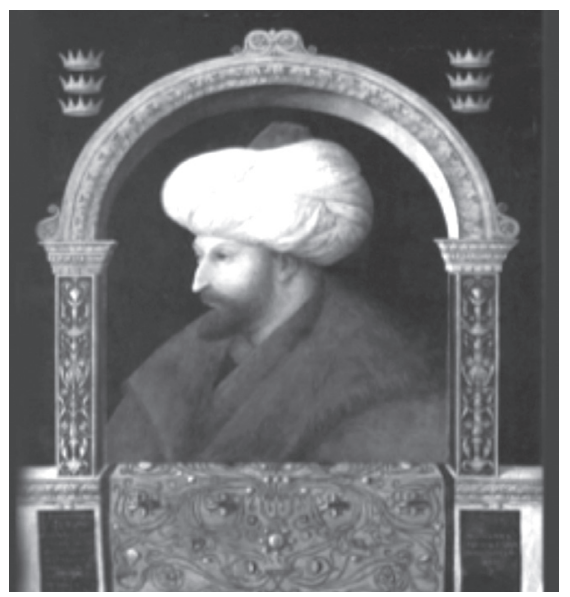

Resim 2. Venedikli Gentile Bellini (1429-1507)'nin, 1480 yılında, İstanbul'da yapmış olduğu portre.

Bellini'nin İstanbul'a gelişinden bir yıl sonra gidişine yakın bir zamanda yapılan Fatih'in bu yağlıboya portre tablosu bugün Londra National Gallery'de bulunmaktadır. Bellini bu portrede Avrupa Rönesans'ının profil veya dörtte üç profil (kişiyi hafifçe dönük gösteren büst kalıbı) kullanmıştır (Renda, 1992: 10). Böylece Fatih'i daha iyi karakterize etme imkanı bulmuştur. Raby (2000), tabloya dair okumasında bu çizimin Fatih'in bireysel ve siyasi kişilikleri arasında gerilim oluşturduğunu savunmaktadır. Belting'in değerlendirmesi Bellini portresinin egemen görme biçimini oldukça iyi özetlemektedir:

"Fatih portresi minyatür resmiyle herhangi bir uzlaşmaya girmez, obje olarak bile daha ziyade Venedik'e uyan baştan aşă̆ı perspektif tekniğiyle yapılmış bir resimdir" (Belting, 2012: 58).

Portredeki kemer ile çerçeve göstergelerine bakarak görkemli bir imparatorluğa dişarıdan bakan bir göze ilk önce "Sultan'ın biricikliği" anlatılmak istenmektedir. İki yanlarda üçer tane olmak 
üzere, yedincisi kumaş üzerinde işli olan yedi taç göstergesinin Osmanlı Hanedanının yedinci padişahı olan Fatih'i anlatmak istediği aktarılmaktadır (Bağcı vd., 2006). Sultanın ulaşılmazlığını, görkemli bir yaşam şeklinin olduğunu ve izleyene sizden biri olmadığı anlamı, işlemeli, yaldızlı kumaş seçimleri, taçlar ve sultanın giydiği kürk ile anlatılmaya çalışılmıştır. Bellini'nin tabloya yazdığ1 “Dünyanın Fatihi" göstergesi ise Sultanın siyasi ve askeri başarılarına ve Fatih' in misyonuna işaret etmektedir (Resim 2).

Fatih Sultan Mehmed'i resmeden iki ayrı sanatçının görme rejimlerinin portrede gönderme yaptığı anlamlar göstergebilimsel yöntemle çözümlenmiştir. Neticede farklı kültürlerden doğan farklı bakış açılarının oluşturduğu görme rejimleri portrede hükümdar imgesi olarak iki ayrı sultan kimliği oluşturmaktadır. Bunun yanısıra Bellini ile Nakkaş Sinan'ın Sultan imgelerinin ayrılan ve benzeşen yanları iki görme kültürünün birbirine ne ölçüde temas ettiğini de düşündürmektedir.

\section{Değerlendirme ve Sonuç}

Göstergebilimsel yöntemle çözümlenen Fatih Sultan Mehmet portrelerinde iki ayrı sanatçının görme rejimlerinin portrede gönderme yaptığı anlamlar değerlendirildiğinde bu çerçevede farklı kültürlerden doğan farklı bakış açılarının oluşturduğu görme rejimleri portrede iki ayrı Hükümdar imgesi oluşturmuş ve iki ayrı Fatih Sultan kimliği alımlanmıştır. Bu bulgu eşliğinde denilebilir ki Rönesans sanatçısı olan ve merkezi perspektif biçimiyle bakan Bellini sanatçı olarak kendisini resim karşısında birey olarak konumlamış Fatih'i de kendi dünya algısının yani Rönesansın maddeyi yücelterek en mükemmeli arayan düşünce ekseni çerçevesinde biricikleştirmiştir. Öte yandan Osmanlı Saray Nakkaşı olan ve minyatür gibi çok merkezli bir görme biçimiyle bakan Sinan Bey ise Doğu kültürünün bir görme biçimi olan temaşa ederek bakmış, yeryüzünde hiçbir canlıya kalıcılık yüklemeyen dünya algısı resme yansımıştır. Analiz kısmında Fatih'in gül koklayan portresinden çıkarım yapılan Rönesans portrelerindeki gibi hafif yana dönük poz tekniği, giysilerin kıvrımlarındaki detaylandırmalar değerlendirildiğinde Nakkaş Sinan'ın Avrupa'da aldığı eğitimi minyatür geleneği içerisinde nasıl Doğu-Batı sentezine dönüştür- 
dügünü kanıtlamaktadır. Fatih döneminin iki görme kültürünün birbirine ne ölçüde temas ettiğinin izini sürmek için seçilen portrelerin isabetli olduğunu, bu çerçevede aynı döneme ait olan bu iki portrenin Fatih'in çok bakışlı, çok kültürlü ve eleştirel görme biçimlerine kapı aralayan Doğu ve Batı tarzı görme biçimlerini kuşatan çok merkezliliğinin bugünün görme ideolojileri ile kıyas edilmesi imkanı sağladığı düşünülmektedir.

Farklı görme rejimleri sanata ve sanatçıya değişik perspektiflerden sanatını icra etme hürriyetini verirken aynı zamanda sanatın muhatabı olan insan ve dolayısıyla topluma da farklı görme biçimleri kazandırmıştır. Perspektifin görme biçimlerini rasyonelleştirmesi, gerçeğin temsili üzerine yaptığı katkı ve bireycilik ile perspektif arasındaki doğru orantı "bakış"ın özündeki değişimlere 1şık tutacak niteliktedir. Dünyayı bireyin baktığı yerden tasavvur eden yeni bir görme ve bilme rejimi dizayn eden perspektifin görme teknolojileriyle yaygınlaşıp, kullanımının yoğunlaşmasının insanın dünyaya bakışını nasıl farklılaştırdığı sorusu ile yüzleşmek kaçınılmaz olmaktadır. Bu çalışmanın önemi "geleneğin sürdürülebilmesi" bağlamında Fatih Sultan döneminde Batılı bir görme biçiminin sonucu olan "portre" nin Doğulu bir görme rejimi olan "minyatür" ün içine eklemlenerek büyük bir geleneğe nasıl dönüştürülebildiğine dikkat çekmektedir. Bugün için Doğu ve Batı' nın bakış biçimlerinin tektipleşmesi, egemen bir görme biçiminin oluşması bu görme rejimlerinin kültürel geçişliliği önünde büyük bir handikap oluşturmaktadır. 


\section{Kaynakça}

AND, M., (2002). Osmanlı Tasvir Sanatları. İş Bankası Kültür Yayınları, İstanbul.

AND, M., (2005). Minyatürlerle Osmanlı-İslam Mitologyası. Yap1 Kredi Yayınları, İstanbul.

ASLANAPA, O., (1972). Türk Sanatı (C:1). Milli Eğitim Basımevi, İstanbul.

ATASOY, N., \& ÇAĞMAN, F.,(1974). Turkish Miniature Painting. İstanbul.

BELTING, H., \& YILMAZER, Z.A. (2012). Floransa ve Bağdat. Koç Üniversitesi Yayınları, İstanbul.

BERGER, J., \& SALMAN, Y. (2016). Görme Biçimleri. Metis Yayınc1lik, İstanbul.

BAĞCI, S., \& ÇAĞMAN, F., RENDA, G., TANINDI, Z., (2006). Osmanlı Resim Sanatı. Mas Matbaacılık T.C. Kültür ve Turizm Bakanlığı Yayınları Sanat Eserleri Dizisi, İstanbul.

BEKSAÇ, E., (2000). Avrupa Sanatına Giriş. Engin Yayıncılık, İstanbul.

BİGALI, Ş., (1984). Resim Sanatı. Şafak Matbaası, Ankara.

ÇAĞMAN, F., \& TANINDI, Z. (1979). Topkapı Sarayı İslâm Minyatürleri. Tercüman Sanat ve Kültür Yayınları, İstanbul.

GOMBRICH, E.H., \& CEMAL, A. (2015). Sanat ve Yanılsama. Remzi Kitabevi, İstanbul.

FARAGO, F., \& DOĞAN Ö. (2006). Sanat. Doğu Batı Yayınları, Ankara.

FLORENSKİ, P. \& TÜKEL, Y. (2013). Tersten Perspektif. Metis Yayıncilık, İstanbul.

HOBSBAWM, E.J., RANCER, T. \& ŞAHIN, M.M. (2006). Geleneğin İcadı. Agora Kitaplığı, İstanbul.

HUBERMAN, L., (2003). Feodal Toplumdan Yirminci Yüzyıla. İletişim Yayınları, İstanbul.

İPŞİROĞLU, M., \& İPŞİROĞLU, N., (2012). Oluşum Süreci İçinde Sanatın Tarihi. Hayalperet Yayınevi, İstanbul. 
KRAUSSE, A.C., \& ZAPTÇIOĞLU, D. (2005). Rönesanstan Günümüze Resim Sanatının Öyküsü. Literatür Yayıncılık, İstanbul.

MAHİR, B., (2012). Osmanlı Minyatür Sanatı. İstanbul.

NECIPOĞLU, G., (2000). Osmanl Sultanlarmmn Portre Dizilerine Karşılaştırmalı Bir Bakış, Padişahın Portresi, Tesâvir-î Âl-i Osman. İstanbul.

PANOFSKY, E., \& TÜKEL, Y. (2012). Perspektif: Simgesel Bir Biçim. Metis Yayınları, İstanbul.

REFIK, A., (2012). Fatih ve Bellini. Yeditepe Yayınevi, İstanbul.

RENDA, G., (1992). Osmanl Padişah Portreleri Bir 19.Yüzyıl Albümü. İnan ve Suna Kıraç Kolleksiyonu, Milano.

TANINDI, Z., (1996). Türk Minyatür Sanatı. Türkiye İş Bankası Kültür Yayınları, Ankara.

TANSUĞ, S., (2004). Resim Sanatınm Tarihi. Remzi Kitabevi, İstanbul.

TANSUĞ, S., (1993). Çağdaş Türk Sanatı. Remzi Kitabevi.

BENJAMIN, W. (2002). Pasajlar, Çev. Ahmet Cemal, 4.

STOREY, J. (2010). Cultural Studies And The Study Of Popular Culture. Edinburgh University Press.

Portresi, P., (2000). Tesavir-i Ali Osman. İstanbul Topkapı Sarayı Müzesi, İstanbul.

İNEL, B., (1999). Osmanlıda Minyatür Sanatına Bir Bakış Ve Resim Sanatının Öncüleri. Türkiye'de Sanat, 41.

RUHI, K., (2013). Turkish Studies International Periodical For The Languages, Literature and History of Turkish or Turkic. Osmanl Minyatür Sanatında Padişah Portreciliğinin Ilk Örnekleri ve Geleneğe Katkıları, Ankara.

NORAH, M.T., (1983). Persian miniature painting and its influence on the art of Turkey and India: The British Library collections.

ÇAĞMAN, F., (1982). Anadolu Türk Minyatürü. Anadolu Uygarlıkları Ansiklopedisi, (C 5, s. 989-994), İstanbul.

INALCIK, H.\& RENDA, G., (2002). Osmanlı Uygarlı̆̆ı.(C 2). T.C Kültür ve Turizm Bakanlığı, Ankara. 
Aslıhan Tonguç

OĞUZHAN, Ö. (2008). Modern Zeminde Deneyimin Düşünümsel Yüzünü Örten Kitlesel Görüntü.

ÇAĞLAR, B. (2012). Bir İletişim Biçimi Olarak Göstergebilim. LAÜ Sosyal Bilimler Dergisi, 3 (2), 22-34. Retrieved from http: / / dergipark.gov.tr/euljss / issue / 6282 / 84320 